\title{
New Triterpenoids from the Stem Barks of Drypetes tessmanniana
}

\author{
Marlise Diane Jiofack Dongfack,${ }^{a, c}$ Hanh Trinh Van-Dufat ${ }^{c}$ Marie-Christine Lallemand, ${ }^{c}$ \\ Jean-Duplex WAnsi, ${ }^{b}$ Elisabeth SEguin, ${ }^{d}$ François TILLEQuin, ${ }^{c}$ and Jean WANDJI ${ }^{*, a}$ \\ ${ }^{a}$ Department of Organic Chemistry, Faculty of Science, University of Yaounde-1; P.O. Box 812 Yaounde, Cameroon: \\ ${ }^{b}$ Department of Chemistry, Faculty of Science, University of Douala; P.O. Box 24157 Douala, Cameroon: ${ }^{c}$ Laboratoire de \\ Pharmacognosie de l'Université Paris Descartes, UMR/CNRS $N^{\circ} 8638$, Faculté des Sciences Biologiques et \\ Pharmaceutiques; 4-Avenue de l'Observatoire, 75006 Paris, France: and ${ }^{d}$ Laboratoire de Pharmacognosie, UFR de \\ Médecine Pharmacie Rouen; 22-Bld Gambetta, 76183 Rouen Cedex 1, France. \\ Received March 6, 2008; accepted May 28, 2008
}

The MeOH extract of the stem barks of Drypetes tessmanniana (Euphorbiaceae) afforded two new triterpene derivatives characterized as $3 \beta-O-(E)-3,5$-dihydroxycinnamoyl-11-oxo-olean-12-ene and $3 \beta, 6 \alpha$-dihydroxylup-20(29)-ene together with seven known compounds. Their structures were established on the basis of spectral analysis.

Key words Drypetes tessmanniana; Euphorbiaceae; (E)-3,5-dihydroxycinnamoyl; acylated triterpene

Plants belonging to the Drypetes genus (Euphorbiaceae) are widely used in traditional medicine in West and Central Africa for the treatment of diverse infections such as sinusitis, swelling, boils, gonorrhoea and dysentery. ${ }^{1-4)}$ Diverse therapeutic applications of the Drypetes plants prompted us to carry out pharmacological and chemical studies on many species. In our previous results, we reported on the antiinflammatory and analgesic actions of a crude extract and compounds isolated from D. molunduana, ${ }^{5-7)}$ phenolic constituents from $D$. armoracia $^{8)}$ and the antileishmanial furanosesquiterpene and triterpenoids from $D$. chevalieri. ${ }^{9)}$ As a continuation of our search for compounds with biological activities from the Drypetes species, we studied the stem bark of D. tessmanniana, a small tree or shrub growing in the eastern forests of Cameroon. We isolated two new triterpene derivatives and seven known compounds. The known compounds were identified as lupeol $(3),{ }^{10)}$ friedelin (4), ${ }^{10)} 3,7$ dioxofriedelane $(5),{ }^{10)} 3,15$-dioxofriedelane $(\mathbf{6}),{ }^{10)}$ friedelan3 -ol (7), ${ }^{10)}$ sitosterol $(\mathbf{8})^{7,8)}$ and $3 \beta$-D-glucopyranosylsitosterol (9). ${ }^{7,8)}$ The structures of the new compounds, on the basis of spectroscopic analysis, have been determined as $3 \beta-O$ $(E)$-3,5-dihydroxycinnamoyl-11-oxo-olean-12-ene (1) and $3 \beta, 6 \alpha$-dihydroxylup-20(29)-ene (2). In the present paper, their isolation and structural determination will be described.

\section{Results and Discussion}

The stem bark of Drypetes tessmanniana was powdered and extracted with $\mathrm{MeOH}$, and the solvent was evaporated under vacuum. The crude extract was chromatographed on a column of silica gel eluted with $n$-hexane, EtOAc and $\mathrm{MeOH}$ in increasing polarities to afford compounds (1-9).

The novel compound (1) was obtained as a colourless amorphous solid. The molecular formula was deduced from the HR-TOF-MS ES ${ }^{+} m / z 602.8491$ (Calcd for $\mathrm{C}_{39} \mathrm{H}_{54} \mathrm{O}_{5}$ : 602.8506) and EI-MS ( $\left.m / z 602\left[\mathrm{M}^{+}\right]\right)$, appropriate for $13 \mathrm{de}-$ grees of unsaturation. Its IR spectrum exhibited strong absorption bands due to free hydroxyl $\left(3390 \mathrm{~cm}^{-1}\right)$, conjugated ester carbonyl $\left(1702 \mathrm{~cm}^{-1}\right)$, enone carbonyl $\left(1685 \mathrm{~cm}^{-1}\right)$, aromatic $\mathrm{C}=\mathrm{C}\left(1605,1514 \mathrm{~cm}^{-1}\right)$ and trans-disubstituted double bonds $\left(1610,975 \mathrm{~cm}^{-1}\right)$. The ${ }^{1} \mathrm{H}-\mathrm{NMR}$ spectrum (Table 1) displayed eight singlet resonances for methyl groups $\left(\delta_{\mathrm{H}} 0.82,0.83,0.88,0.96,1.00,1.10,1.29,1.37\right) \mathrm{sug}$ -
Table 1. ${ }^{1} \mathrm{H}$ - and ${ }^{13} \mathrm{C}-\mathrm{NMR}(400,100 \mathrm{MHz})$ Data ${ }^{a}$ of Compounds 1 $\left(\mathrm{C}_{5} \mathrm{D}_{5} \mathrm{~N}\right)$ and $2\left(\mathrm{CDCl}_{3}\right)$

\begin{tabular}{|c|c|c|c|c|}
\hline \multirow{2}{*}{ Attributions } & \multicolumn{2}{|r|}{1} & \multicolumn{2}{|r|}{2} \\
\hline & $\delta_{\mathrm{C}}$ & $\delta_{\mathrm{H}} J(\mathrm{~Hz})$ & $\delta_{\mathrm{C}}$ & $\delta_{\mathrm{H}} J(\mathrm{~Hz})$ \\
\hline 1 & 39.1 & $1.18 \mathrm{~m} ; 1.22 \mathrm{~m}$ & 38.5 & $0.89 \mathrm{~m} ; 1.62^{b)} \mathrm{m}$ \\
\hline 2 & 24.2 & $1.83 \mathrm{~m} ; 1.91 \mathrm{~m}$ & 27.0 & $1.57 \mathrm{~m} ; 1.67^{b)} \mathrm{m}$ \\
\hline 3 & 80.2 & $4.90 \mathrm{dd}(4.8 ; 11.1)$ & 78.7 & $3.20 \mathrm{dd}(5.6 ; 10.7)$ \\
\hline 4 & 38.5 & & 39.1 & \\
\hline 5 & 55.1 & $1.85 \mathrm{~m}$ & 60.6 & $0.78 \mathrm{~d}(10.3)$ \\
\hline 6 & 18.8 & $1.40 \mathrm{~m} ; 1.53 \mathrm{~m}$ & 68.8 & $4.10 \operatorname{td}(3.4,10.3)$ \\
\hline 7 & 33.0 & $1.28 \mathrm{~m} ; 1.60 \mathrm{~m}$ & 46.7 & $1.40 \mathrm{~m} ; 1.67^{b)} \mathrm{m}$ \\
\hline 8 & 45.2 & & 42.1 & \\
\hline 9 & 61.9 & $2.45 \mathrm{~s}$ & 49.9 & $1.27 \mathrm{~m}$ \\
\hline 10 & 37.4 & & 39.3 & \\
\hline 11 & 199.4 & & 20.8 & $1.65 \mathrm{~m} ; 1.66 \mathrm{~m}$ \\
\hline 12 & 128.3 & $5.75 \mathrm{~s}$ & 25.0 & $1.03 \mathrm{~m} ; 1.64 \mathrm{~m}$ \\
\hline 13 & 170.2 & & 37.6 & $1.61^{b)} \mathrm{m}$ \\
\hline 14 & 43.6 & & 43.0 & \\
\hline 15 & 26.7 & $1.07 \mathrm{~m} ; 1.72 \mathrm{~m}$ & 27.4 & $0.99 \mathrm{~m}$ \\
\hline 16 & 26.5 & $1.69 \mathrm{~m} ; 2.03 \mathrm{~m}$ & 35.5 & $1.34 \mathrm{~m} ; 1.46^{b)} \mathrm{m}$ \\
\hline 17 & 32.5 & & 42.9 & \\
\hline 18 & 45.5 & $1.67 \mathrm{~s}$ & 48.3 & $1.46^{b)} \mathrm{m}$ \\
\hline 19 & 47.7 & $2.09 \mathrm{~m} ; 2.12 \mathrm{~m}$ & 47.9 & $2.35 \mathrm{dt}(10.3,6.5)$ \\
\hline 20 & 31.1 & & 150.8 & \\
\hline 21 & 34.6 & $1.08 \mathrm{~m} ; 1.35 \mathrm{~m}$ & 29.8 & $1.20 \mathrm{~m} ; 1.88 \mathrm{~m}$ \\
\hline 22 & 36.7 & $1.21 \mathrm{~m} ; 1.43 \mathrm{~m}$ & 39.9 & $1.16 \mathrm{~m} ; 1.37 \mathrm{~m}$ \\
\hline 23 & 28.7 & $1.00 \mathrm{~s}$ & 30.9 & $1.32 \mathrm{~s}$ \\
\hline 24 & 16.7 & $0.96 \mathrm{~s}$ & 15.5 & $0.98 \mathrm{~s}$ \\
\hline 25 & 17.1 & $1.37 \mathrm{~s}$ & 17.1 & $0.85 \mathrm{~s}$ \\
\hline 26 & 17.6 & $1.10 \mathrm{~s}$ & 17.5 & $1.08 \mathrm{~s}$ \\
\hline 27 & 23.5 & $1.29 \mathrm{~s}$ & 14.5 & $0.96 \mathrm{~s}$ \\
\hline 28 & 28.2 & $0.82 \mathrm{~s}$ & 18.0 & $0.75 \mathrm{~s}$ \\
\hline 29 & 32.7 & $0.88 \mathrm{~s}$ & 109.4 & $\begin{array}{l}4.58 \mathrm{~d}(2.3) \\
4.68 \mathrm{~d}(2.3)\end{array}$ \\
\hline 30 & 23.6 & $0.83 \mathrm{~s}$ & 19.3 & $1.68 \mathrm{~s}$ \\
\hline $1^{\prime}$ & 128.4 & & & \\
\hline $2^{\prime}$ & 116.7 & $7.23 \mathrm{~s}$ & & \\
\hline $3^{\prime}$ & 147.7 & & & \\
\hline $4^{\prime}$ & 122.0 & $7.69 \mathrm{~s}$ & & \\
\hline $5^{\prime}$ & 150.4 & & & \\
\hline $6^{\prime}$ & 115.6 & $7.23 \mathrm{~s}$ & & \\
\hline $7^{\prime}$ & 145.6 & $8.00 \mathrm{~d}(15.8)$ & & \\
\hline $8^{\prime}$ & 115.9 & $6.66 \mathrm{~d}(15.8)$ & & \\
\hline $9^{\prime}$ & 167.3 & & & \\
\hline
\end{tabular}

a) Assignments were accomplished using HSQC, HMBC, ${ }^{1} \mathrm{H}-{ }^{1} \mathrm{H}$ COSY and NOESY experiments. $b$ ) Overlapping signals. 
gesting the triterpene skeleton, one singlet at $\delta_{\mathrm{H}} 5.75$ assigned to the proton of the enone group, and one doublet of doublet at $\delta_{\mathrm{H}} 4.90(1 \mathrm{H}, J=4.8 ; 11.1 \mathrm{~Hz})$ assigned to the 3oxymethine proton. It also exhibited two singlet resonances for three aromatic protons at $\delta_{\mathrm{H}} 7.23(2 \mathrm{H})$ and $\delta_{\mathrm{H}} 7.69(1 \mathrm{H})$ and two doublet signals at $\delta_{\mathrm{H}} 6.66(1 \mathrm{H}, J=15.8 \mathrm{~Hz})$, and $\delta_{\mathrm{H}}$ $8.00(1 \mathrm{H}, J=15.8 \mathrm{~Hz})$. These data suggested the presence of the 3,5-dihydroxycinnamoyl moiety in (1). The ${ }^{13} \mathrm{C}-\mathrm{NMR}$ spectrum (Table 1) showed signals for 39 carbons including 30 carbons for the triterpene skeleton and 9 carbons for the cinnamoyl moiety. The structure of the 3,5-dihydroxycinnamoyl moiety was confirmed by the HMBC spectrum (Fig. 2 ) which displayed long range correlations from protons $\mathrm{H}$ $2^{\prime} / \mathrm{H}-6^{\prime}\left(\delta_{\mathrm{H}} 7.23 ;\right.$ s $)$ to carbons C-3' $\left(\delta_{\mathrm{C}} 147.7\right), \mathrm{C}-5^{\prime}\left(\delta_{\mathrm{C}}\right.$ $150.4)$ and $\mathrm{C}-7^{\prime}\left(\delta_{\mathrm{C}} 145.6\right)$. This group was placed at the $\mathrm{C}-3$ position as deduced from the downfield shift observed for proton $\mathrm{H}-3\left(\delta_{\mathrm{H}} 4.90\right)$ and the crossed peaks exhibited in the HMBC spectrum from proton $\mathrm{H}-3\left(\delta_{\mathrm{H}} 4.90\right)$ to carbons $\mathrm{C}-1$ $\left(\delta_{\mathrm{C}} 39.1\right), \mathrm{C}-24$ (16.7) and C-9' $(167.3)$. The $\beta$-orientation of the ester group was determined using $\mathrm{H}-3 \alpha$ coupling constant $\left(J_{\text {trans }}=11.1 \mathrm{~Hz}\right)$ and the NOESY spectrum which showed crossed peaks between both protons $\mathrm{H}-3\left(\delta_{\mathrm{H}} 4.90\right)$ and $\mathrm{H}-5\left(\delta_{\mathrm{H}} 1.85\right)$. The presence of the enone in $(\mathbf{1})$ was confirmed by the carbon resonances at $\delta_{\mathrm{C}} 199.4(\mathrm{C}-11), 128.3$ (C-12) and 170.2 (C-13). The HMBC spectrum also displayed crossed peaks between proton $\mathrm{H}-12\left(\delta_{\mathrm{H}} 5.75\right)$ and carbons C-9 $\left(\delta_{\mathrm{C}} 61.9\right), \mathrm{C}-11(199.4)$ and C-13 (170.2). The ${ }^{1} \mathrm{H}-$ and ${ }^{13} \mathrm{C}$-NMR signals of the triterpene moiety were similar to

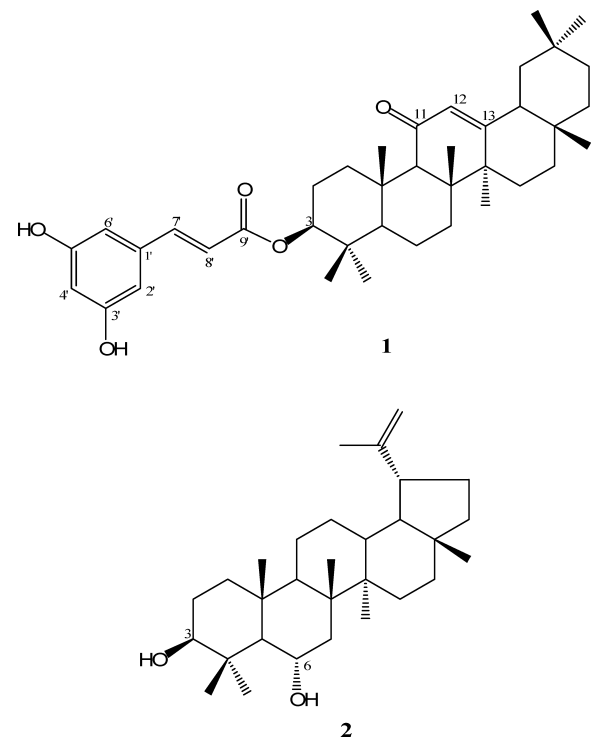

Fig. 1. Structures of Compounds $\mathbf{1}$ and $\mathbf{2}$

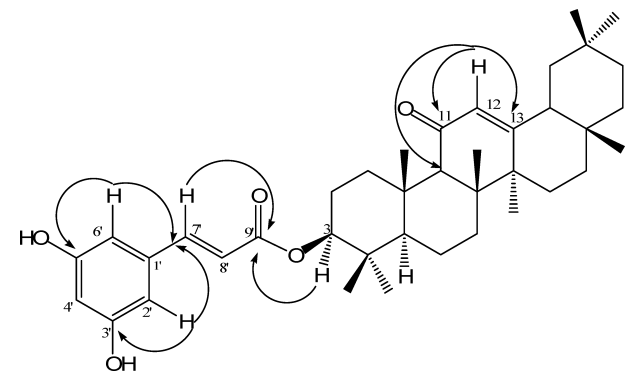

Fig. 2. Important HMBC Correlations in Compound $\mathbf{1}$ those of $3 \beta$-hydroxy-olean-12-en-11-one reported in the literature. ${ }^{11)}$ Thus compound 1 was established to be $3 \beta-O-(E)$ 3,5-dihydroxycinnamoyl-11-oxo-olean-12-ene (Fig. 1). To the best of our knowledge, the compound reported here is one of the rare examples of acylated triterpenes with an unusual phenylpropanoid, (E)-3,5-dihydroxycinnamic acid moiety. ${ }^{12)}$ A number of studies have reported on the isolation of acylated triterpenes from plants and some have demonstrated diverse biological properties including cytotoxic, ${ }^{13)}$ antitumor ${ }^{14,15)}$ and anti-inflammatory ${ }^{16)}$ activities.

Compound 2 was obtained as a colourless amorphous solid. The pseudo molecular ion peaks at $m / z 443[\mathrm{M}+\mathrm{H}]^{+}$ and $460\left[\mathrm{M}+\mathrm{NH}_{4}\right]^{+}$in its $\mathrm{CI} / \mathrm{NH}_{3} \mathrm{MS}$ and the HR-TOF-MS $\mathrm{ES}^{+}(m / z$ 442.3825) suggested its molecular formula to be $\mathrm{C}_{30} \mathrm{H}_{50} \mathrm{O}_{2}$. The IR spectrum indicated the presence of hydroxyl $\left(3400 \mathrm{~cm}^{-1}\right)$ and olefinic $\left(1660 \mathrm{~cm}^{-1}\right)$ groups. The ${ }^{1} \mathrm{H}-$ NMR spectrum of 2 (Table 1) displayed six tertiary methyl singlet signals $\left(\delta_{\mathrm{H}} 1.32,1.08,0.98,0.96,0.85,0.75\right)$, one isopropenyl group $\left[\delta_{\mathrm{H}} 1.68(3 \mathrm{H}, \mathrm{s}), 4.58\right.$ and $4.68(1 \mathrm{H}$ each, $\mathrm{d}, J=2.3 \mathrm{~Hz})]$ and two oxymethine protons $\left(\delta_{\mathrm{H}} 3.20,4.10\right)$, while the ${ }^{13} \mathrm{C}$-NMR spectrum showed 30 carbon signals including seven methyls, nine methylenes, seven (two of which are oxygenated) methines, and six quaternary carbons (Table 1). On the basis of the analysis of the ${ }^{1} \mathrm{H}-{ }^{1} \mathrm{H}$ COSY, HMQC and DEPT spectra, 2 was suggested to be a lupane-type triterpene bearing two hydroxyl groups. The EI-MS of $\mathbf{2}$ exhibited important peaks at $m / z 442[\mathrm{M}]^{+}, 424\left[\mathrm{M}-\mathrm{H}_{2} \mathrm{O}\right]^{+}$, $409\left[\mathrm{M}-\mathrm{H}_{2} \mathrm{O}-\mathrm{CH}_{3}\right]^{+}, 406\left[\mathrm{M}-2 \mathrm{H}_{2} \mathrm{O}\right]^{+}, 236,218,205$, 203 , and 189. This fragmentation pattern supported the lup20(29)-ene skeleton with the location of both hydroxyl groups on rings $\mathrm{A}$ and $\mathrm{B}$. The positions of the two hydroxyl groups were established on the basis of the HMBC and NOESY (Fig. 3) experiments. The HMBC spectrum of $\mathbf{2}$ showed correlations between the oxymethine proton at $\delta_{\mathrm{H}}$ 3.20 and the carbons $\mathrm{C}-2\left(\delta_{\mathrm{C}} 27.0\right), \mathrm{C}-4\left(\delta_{\mathrm{C}} 39.1\right), \mathrm{C}-5\left(\delta_{\mathrm{C}}\right.$ $60.6), \mathrm{C}-23\left(\delta_{\mathrm{C}} 30.9\right)$, and $\mathrm{C}-24\left(\delta_{\mathrm{C}} 15.5\right)$, confirming the location of one hydroxyl group at $\mathrm{C}-3$. The $3 \beta-\mathrm{OH}$ equatorial orientation was established using $\mathrm{H}-3 \alpha$ coupling constant $\left(J_{\text {trans }}=10.7 \mathrm{~Hz}\right)$ and the interaction observed in the NOESY spectrum, between the two axial protons $\mathrm{H}-3 \alpha\left(\delta_{\mathrm{H}} 3.20\right)$ and H-5 $\left(\delta_{\mathrm{H}} 0.78\right)$. Furthermore, the HMBC spectrum exhibited interactions between the second oxymethine proton at $\delta_{\mathrm{H}}$ 4.10 and the carbons C-4 $\left(\delta_{\mathrm{C}} 39.1\right), \mathrm{C}-5\left(\delta_{\mathrm{C}} 60.6\right), \mathrm{C}-7\left(\delta_{\mathrm{C}}\right.$ $46.7), \mathrm{C}-8\left(\delta_{\mathrm{C}} 42.1\right)$, and $\mathrm{C}-10\left(\delta_{\mathrm{C}} 39.3\right)$. These data suggested the second hydroxyl group to be located at C-6. The NOESY spectrum displayed important correlations between the proton $\mathrm{H}-6\left(\delta_{\mathrm{H}} 4.10\right)$ and the methyl protons $\mathrm{CH}_{3}-24\left(\delta_{\mathrm{H}}\right.$ $0.98), \mathrm{CH}_{3}-25\left(\delta_{\mathrm{H}} 0.85\right)$, and $\mathrm{CH}_{3}-26\left(\delta_{\mathrm{H}} 1.08\right)$, suggesting the $\beta$-axial orientation of the proton $\mathrm{H}-6$. Consequently, OH6 was deduced to have the $\alpha$-equatorial orientation. Further arguments were given by the H-6 $\beta$ coupling constant (td, $J=3.4,10.3 \mathrm{~Hz}$ ) which was similar to the reported values. ${ }^{17)}$

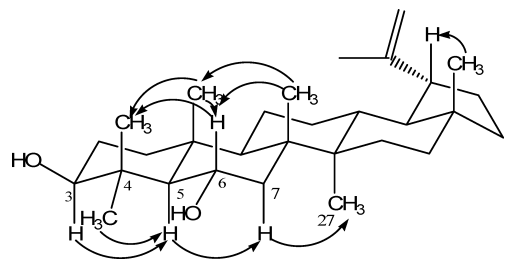

Fig. 3. Important NOESY Correlations in Compound 2 
In addition, the ${ }^{13} \mathrm{C}-\mathrm{NMR}$ spectrum of $\mathbf{2}$ (Table 1) exhibited the important and characteristic signal for carbon C-5 at $\delta_{\mathrm{C}}$ 60.6 that was higher $(c a .4-5 \mathrm{ppm})$ than some reported data for C-5 ( $c a .55 .4-56.6 \mathrm{ppm})$ in similar triterpenes with a $6 \beta$-OH group. ${ }^{18-20)}$ Therefore, the structure of compound 2 was established as $3 \beta, 6 \alpha$-dihydroxylup-20(29)-ene (Fig. 1). The same structure was reported in the literature, ${ }^{21)}$ but, in the ${ }^{13} \mathrm{C}$-NMR data published, the carbon $\mathrm{C}-5$ was assigned at $\delta_{\mathrm{C}} 55.4$; this value should correspond, in agreement with the literature values, to the $6 \beta$-OH orientation, and not to the $6 \alpha$ $\mathrm{OH}$ as attributed. Consequently, the reported structure might be wrong and should be revised.

\section{Experimental}

General The MPs were determined using a Kofler microhot stage apparatus. Optical rotations were measured on a Perkin-Elmer 241 polarimeter IR spectra $\left(v_{\max }\right.$ in $\left.\mathrm{cm}^{-1}\right)$ were obtained from potassium pellets on a Nicolet 510 FT instrument. Mass spectra were recorded with ZQ 2000 Waters and Q-Tof1 Micromass spectrometers using electro spray ionization (ESI-MS: $\mathrm{U}_{\mathrm{c}}=30 \mathrm{~V}$ ), a Nermag R10-10C spectrometer and a HP-5973 Mass Selective Detector. ${ }^{1} \mathrm{H}-\mathrm{NMR}(\delta[\mathrm{ppm}], J[\mathrm{~Hz}])$ and ${ }^{13} \mathrm{C}-\mathrm{NMR}$ spectra were recorded at $400 \mathrm{MHz}$ and $100 \mathrm{MHz}$, respectively, using a Bruker AC 400 spectrometer and a Varian Gemini $400 \mathrm{MHz}$ instrument. Multi-impulsional 2D NMR experiments $\left({ }^{1} \mathrm{H}-{ }^{1} \mathrm{H}\right.$ COSY, ${ }^{1} \mathrm{H}-1 \mathrm{H}$ NOESY, ${ }^{13} \mathrm{C}-{ }^{1} \mathrm{H}$ HSQC,${ }^{13} \mathrm{C}-{ }^{1} \mathrm{H}$ HMBC $)$ were performed using standard Bruker or Varian Gemini micro-programs. Silica gel 60 ( 70 - 230 mesh) was used for column chromatography at normal pressure while silica gel $60 \mathrm{H}(5-40 \mu \mathrm{m})$ and $60 \mathrm{AC}(20-40 \mu \mathrm{m})$ were used for column chromatography under compressed air $(300 \mathrm{mbar})$. Precoated silica gel $60 \mathrm{~F}_{254}$ aluminium plates were used for thin layer chromatography and eluted with mixtures of solvents such as hexane $/ \mathrm{CH}_{2} \mathrm{Cl}_{2}$ (9:1); $\mathrm{CH}_{2} \mathrm{Cl}_{2} / \mathrm{MeOH}(19: 1) ; \mathrm{CH}_{2} \mathrm{Cl}_{2} / \mathrm{MeOH}(9: 1)$.

Plant Material The stem barks of Drypetes tessmanniana (Euphorbiaceae) were collected from the Dja forest (East Cameroon), in November 2005. The herbarium specimen documenting the collection has been deposited in the National Herbarium Cameroon, Yaoundé, under Ref. No. 5677/SRFCAM.

Extraction and Isolation The dried powdered stem bark $(6 \mathrm{~kg})$ of Drypetes tessmanniana was extracted with $\mathrm{MeOH}$ at room temperature and concentrated to dryness under reduced pressure to yield a brown semi-solid residue $(200 \mathrm{~g})$. Part of the crude extract $(150 \mathrm{~g})$ was subjected to CC (column chromatography) on silica gel ( $70-230$ mesh). Elution was carried out with hexane, EtOAc and $\mathrm{CH}_{3} \mathrm{OH}$ in increasing polarity. A total of 185 fractions, $200 \mathrm{ml}$ each, were eluted and the TLC permitted to combine the resulted fractions into four series, A-D. Further CC of series A (30 g), fractions $1-29$ using hexane and EtOAc in increasing polarity yielded compounds (3) (24 mg), (4) (15 mg), (5) (15 mg), (6) (10 mg), (7) (150 mg) and (8) (35 mg). Further CC of series B (30 g), fractions 30-121, on silica gel $60 \mathrm{AC}(40-70 \mu \mathrm{m})$ eluting with hexane/EtOAc and EtOAc/MeOH in increasing proportions yielded compounds (1) $(20 \mathrm{mg})$ and (2) $(15 \mathrm{mg})$. Further CC of series C $(20 \mathrm{~g})$, fractions $122-154$ on silica gel 60 AC (40$70 \mu \mathrm{m}$ ) using EtOAc/MeOH in increasing polarity yielded compound (9) (30 mg).

3 $\beta-O-(E)-3,5$-Dihydroxycinnamoyl-11-oxo-olean-12-ene (1): Colourless amorphous solid; TLC Rf: $0.7\left(\mathrm{CH}_{2} \mathrm{Cl}_{2} / \mathrm{MeOH} ; 9: 1\right)$; yellow spot developed on spraying with aqueous $\mathrm{H}_{2} \mathrm{SO}_{4}(50 \%)$. ${ }^{1} \mathrm{H}$ - and ${ }^{13} \mathrm{C}-\mathrm{NMR}$ spectral data $\left(400,100 \mathrm{MHz}, \mathrm{C}_{5} \mathrm{D}_{5} \mathrm{~N}\right)$, see Table 1. IR $(\mathrm{KBr}) \mathrm{cm}^{-1}: 3390,1702,1685$, $1610,1605,1514,975$. HR-TOF-MS $\mathrm{ES}^{+} \mathrm{m} / \mathrm{z}$ : 602.8491 (Calcd for $\mathrm{C}_{39} \mathrm{H}_{54} \mathrm{O}_{5}:$ 602.8506). EI-MS $(70 \mathrm{eV}) \mathrm{m} / z: 602\left(\mathrm{M}^{+}\right), 601,423,273,232$, 231 and $163 .[\alpha]_{\mathrm{D}}^{20}+34.5^{\circ}(c=0.70, \mathrm{MeOH})$

$3 \beta, 6 \alpha$-Dihydroxylup-20(29)-ene (2): Colourless amorphous solid; ${ }^{1} \mathrm{H}-$ and ${ }^{13} \mathrm{C}-\mathrm{NMR}$ spectral data $\left(400,100 \mathrm{MHz}, \mathrm{CDCl}_{3}\right)$, see Table 1 . IR $(\mathrm{KBr})$ $\mathrm{cm}^{-1}: 3400,3030,1660,1260,1180,890$. HR-TOF-MS ES ${ }^{+} \mathrm{m} / z: 442.3825$ (Calcd for $\left.\mathrm{C}_{30} \mathrm{H}_{50} \mathrm{O}_{2}: 442.3811\right)$. $[\alpha]_{\mathrm{D}}^{20}+24.5^{\circ}\left(c=0.60, \mathrm{CHCl}_{3}\right)$. CI/ $\mathrm{NH}_{3}$ MS, $m / z: 443[\mathrm{M}+\mathrm{H}]^{+}, 460\left[\mathrm{M}+\mathrm{NH}_{4}\right]^{+}$. EI-MS $(70 \mathrm{eV}) \mathrm{m} / z: 442\left(\mathrm{M}^{+}\right), 424$ $\left(\mathrm{M}-\mathrm{H}_{2} \mathrm{O}\right)^{+}, 409\left(\mathrm{M}-\mathrm{H}_{2} \mathrm{O}-\mathrm{CH}_{3}\right)^{+}, 406\left(\mathrm{M}-2 \mathrm{H}_{2} \mathrm{O}\right)^{+}, 236,218,205,203$, 189.

Acknowledgements The authors are grateful for grant (No. F/2624-3F) from the International Foundation for Science (Sweden), and to the sponsorship of the "Université Paris Descartes, France" and "Agence Universitaire de la Francophonie" (AUF) for a Doctorate scholarship.

\section{References}

1) Bouquet A., Debray L., "Plantes Médicinales de la Côte-d'Ivoire," Travaux et documents de l'ORSTOM No. 32, 1974, pp. 82-87.

2) Dalziel J. M., "The Useful Plants of West Tropical Africa," The Crown Agents for the Colonies, London, 1937, pp. 140-141.

3) Irvine R. F., "Woody Plants of Ghana," Oxford University Press, London, 1961, pp. 223-226.

4) Walker A. R., Sillans R., Trochain, J. L., "Les Plantes utiles du Gabon," ed. by Lechevalier P., 12-Rue de Tournon Paris VI, Paris, 1961, pp. 165-166.

5) Wandji J., Wansi J. D., Fuendjiep V., Dagne E., Mulholland A. D., Tillequin F., Sondengam B. L., Fuendiep V., Nkeh B. C., Njamen D., Phytochemistry, 54, 811-815 (2000).

6) Chungag-Anye N. B., Njamen D., Dongmo A. B., Wandji J., Nguelefack T. B., Wansi J. D., Kamanyi A., Fomum Z. T., Pharmacol. Lett., 11, 61-63 (2001).

7) Chungag-Anye N. B., Njamen D., Dongmo A. B., Wandji J., Fomum Z. T., Nguelefack T. B., Kamanyi A., Pharmaceut. Biol., 41, 26-30 (2002).

8) Wandji J., Tillequin F., Mulholland A. D., Temgoua D. A., Wansi J. D., Seguin E., Fomum Z. T., Phytochemistry, 63, 453-456 (2003).

9) Wansi J. D., Wandji J., Lallemand M. C., Chiozem D. D., Iqbal M. C., Tillequin F., Fomum T. Z., BLACPMA, 6, 5-10 (2007).

10) Mahato S. B., Kundu A. P., Phytochemistry, 37, 1517-1575 (1994).

11) Bandaranayake, Wickramasinghe M., Phytochemistry, 19, 255-257 (1980).

12) Xu Y. N., Kim J. S., Kang S. S., Son K. H., Kim H. P., Chang H. W., Bae K. H., Chem. Pharm. Bull., 50, 1124-1125 (2002).

13) Yun B.-S., Ryoo I.-J., Lee I.-K., Park K.-H., Choung D.-H., Han K.-H., Yoo I.-D., J. Nat. Prod., 62, $764-766$ (1999).

14) Gu J.-Q., Park E.-J., Luyengi L., Hawtorne M. E., Mehta R. G., Fansworth N. R., Pezzuto J. M., Kinghorn A. D., Phytochemistry, 58, $121-127(2001)$.

15) Taniguchi S., Imayoshi Y., Kobayashi E., Takamashu Y., Ito H., Hatano T., Sakagami H., Tokuda H., Nishino H., Sugita D., Shimura S., Yoshida T., Phytochemistry, 59, 315-323 (2002).

16) De Miranda A. L., Silva J. R. A., Rezende C. M., Neves J. S., Parrini S. C., Pinheiro M. L. B., Cordeiro M. C., Tamborini E., Pinto A. C., Planta Med., 66, 284-286 (2000).

17) Ya-Ching S., Chaturvedula V. S. P., Li-Tang W., Ching-Te C., MengChieh H., J. Nat. Prod., 65, 1052-1055 (2002).

18) Zhi-Hong J., Takashi T., Isao K., Phytochemistry, 40, 1223-1226 (1995).

19) Adnyana I. K., Tezuka Y., Banskota A. H., Tran K. Q., Kadota S., J. Nat. Prod., 64, 360-363 (2001).

20) Nünez Marvin J., Reyes C. P., Jiménez I. A., Moujir L., Bazzochi I. L., J. Nat. Prod., 68, 1018-1021 (2005).

21) Ghulam M., Erum A., Saeed A., Itrat A., Habib A., Abdul M., Syed Su-H., Iqbal M. C., J. Nat. Prod., 63, 881—883 (2000). 